\title{
Assessing the Crop Growing Period According to the Climate Change Forecasts for Marina Baixa (SE Spain)
}

\author{
Mario Herrera ${ }^{1^{*}}$, Hassane Moutahir ${ }^{2,3 *}$, Carlos Alberto González ${ }^{4}$, Esteban Chirino5, \\ Juan Bellot ${ }^{2,3}$ \\ ${ }^{1}$ Department of Life Sciences, University State Amazonia, Puyo, Ecuador \\ ${ }^{2}$ Department of Ecology, University of Alicante, Alicante, Spain \\ ${ }^{3}$ Multidisciplinary Institute for Environmental Studies "Ramón Margalef", University of Alicante, Alicante, Spain \\ ${ }^{4}$ AdMobilze.Computer Vision Engineer, Miami, FL, USA \\ ${ }^{5}$ Faculty of Natural Resources, Polytechnic Higher School of Chimborazo (ESPOCH), Riobamba, Ecuador \\ Email: ${ }^{*}$ mherrera@uea.edu.ec, hassane moutahir@yahoo.fr
}

Received 4 June 2015; accepted 23 September 2015; published 29 September 2015

Copyright (C) 2015 by authors and Scientific Research Publishing Inc.

This work is licensed under the Creative Commons Attribution International License (CC BY).

http://creativecommons.org/licenses/by/4.0/

(c) $\underset{\mathrm{EY}}{\mathrm{EY}}$ Open Access

\section{Abstract}

The present work aims to assess the likely effects of climate change on the length of growing period (LGP) of crops in Marina Baixa (SE, Spain). LGP can be assessed by a balance between precipitation and reference evapotranspiration. Less rainfall and an increased evapotranspiration, forecast by Global Climate Models (GCMs), are considered as a high risk for agriculture. This area is located in a semiarid climate region where water is a very limited resource. It is a typical example of areas where the agricultural sector has to compete for water with the tourism industry. In this context, by using observed and projected precipitation data set (model HadCM3, Scenario A2), calculating reference evapotranspiration (ETo), and applying the frequency analysis of a probability-type method, we estimated the growing period length in the observed period (1961-1990) and three 30-year future periods $(2011-40,2041-70$ and 2071-99) in the study area. The results show a drop in annual precipitations $(-30 \%)$ and an increased ETo $(+18 \%)$ towards the end of this century with respect to the observed period (mean annual rainfall: $356 \mathrm{~mm}$; mean ETo: 1476 $\mathrm{mm}$ ). The results also show a decrease in the number of decades (10 days) when precipitation exceeds half of the ETo, which means shorter growing periods as the $21^{\text {st }}$ century advances. This expected reduction in growing period length towards the end of the present century will imply that many rainfed crops, like olives, almonds and cereals, will require a higher irrigation water supply to maintain suitable growth and performance levels. The results are an early warning to manage water resources in Marina Baixa in a sustainable way.

\footnotetext{
${ }^{*}$ Corresponding author.
} 


\section{Keywords}

\section{Climate Change, Growing Period, Frequency Analysis, Semiarid, Mediterranean}

\section{Introduction}

Global climate change is an unquestionable process. From the 1950s to the present day, it has been scientifically demonstrated that the atmosphere and ocean have warmed, volumes of snow and ice have decreased, the sea level has risen, and concentrations of greenhouse gases have increased. On a global scale, an increase of $0.6^{\circ} \mathrm{C} \pm$ $0.2^{\circ} \mathrm{C}$ in the mean air temperature has been observed since 1861 and forecasts predict an increase of $2^{\circ} \mathrm{C}-4^{\circ} \mathrm{C}$ over the next 100 years. More frequent intense and extreme weather events (including drought and floods) are also expected [1] [2]. The scientific community has reached a broad consensus about the impact and consequences of climate change on plant biodiversity [3]-[5], especially on agriculture. Climate change will produce changes in the spatial plant distribution on a regional scale as a result of changes in rainfall and air temperature. Long-lasting climatic changes are likely to cause geographical shifts of the main plant species and even of the ecosystems [6].

In the Mediterranean region, an increase of $2^{\circ} \mathrm{C}$ in mean air temperatures in the second half of this century is expected [7] [8]. A decrease in precipitations and more frequent long-lasting extreme weather events including severe droughts, heat waves and heavy rainfall events are also expected in this region. These changes in the climatic conditions will affect the agricultural production which is one of the main economic activities in the Mediterranean area. Indeed, prolonged periods of time with less precipitation and high reference evapotranspiration (ETo) rates, due to rising temperatures, will affect the crop growing period. Shorter growing period means reduced crops productivity. Studies and programmes of adaptation to climate change will be an adequate way to mitigate the damage that climate change could cause. For this purpose, assessments of future climatic changes based on Global Climate Models (GCMs) can help to define early warning systems to prevent climate change effects. The Intergovernmental Panel on Climate Change (IPCC) provides a set of GCMs (e.g., HadCM3, ECHAM4, CGCM2, etc.) with a well standardised group of scenarios (e.g., A1B, A2, B1, B2, etc.) for climate impact studies. The database of these models presents certain levels of uncertainty due to multiple factors.

A change in the variance of a distribution will have a larger effect on the frequency of extremes than a change in the mean [9]. An analysis of climatic data dedicated to detect trends on extreme events may not be the appropriate analysis due to the fortuitous behavior of these events. Therefore, it is recommended to establish the frequency of occurrence of these events and to correlate it with their observed variability, instead of adopting the mean values of climatic variables. In this context, the objectives of this study are: 1) to assess the temporal and spatial variation of the climatic conditions in the Marina Baixa region from the observed period (1961-1990) to the end of the $21^{\text {st }}$ century, using the Agroclim-Map ${ }^{\circledR}$ software; 2) to assess the potential effect of climate change forecasts on the crop growing period length (LGP) in the study area.

\section{Materials and Methods}

\subsection{Study Area}

The study was conducted in the Marina Baixa region in the province of Alicante, SE Spain (Figure 1). This region covers an area of $578.7 \mathrm{~km}^{2}$ and encloses 18 municipalities. Climate is characterised by high inter-annual variability of rainfall. The predominant soil type in the region is the Entisol which shows erosion processes and insufficient vegetation cover affected by torrential rain [10]. Altitudes in the region go from more than 1500 (Sierra Aitana: 1558) to 0 m.a.s.l. in the coastline. This topography produces strong climatic contrasts between continental inland and the Mediterranean coastal areas. This region includes three watersheds (Algar River, $216.2 \mathrm{~km}^{2}$, Guadalest River, $122.5 \mathrm{~km}^{2}$ and Amadorio River, $205.2 \mathrm{~km}^{2}$ ) and three aquifer systems (Sierra Bernia, $90 \mathrm{~km}^{2}$, SerrellaAixorta, $40 \mathrm{~km}^{2}$ and Sierra de Aitana, $255 \mathrm{~km}^{2}$ ). Agriculture and tourism have been the main economic activities in the region for decades. Farmlands in Marina Baixa cover 8582 ha and more of the half of this area is covered by rainfed crops (4775 ha), where non-citrus fruit trees, olives and cereals cover 3093 ha, 1400 ha and 282 ha respectively. Irrigated crops (3807 ha) are dominated by citrus (1820 ha) and non-citrus fruit trees (1550 ha.). 


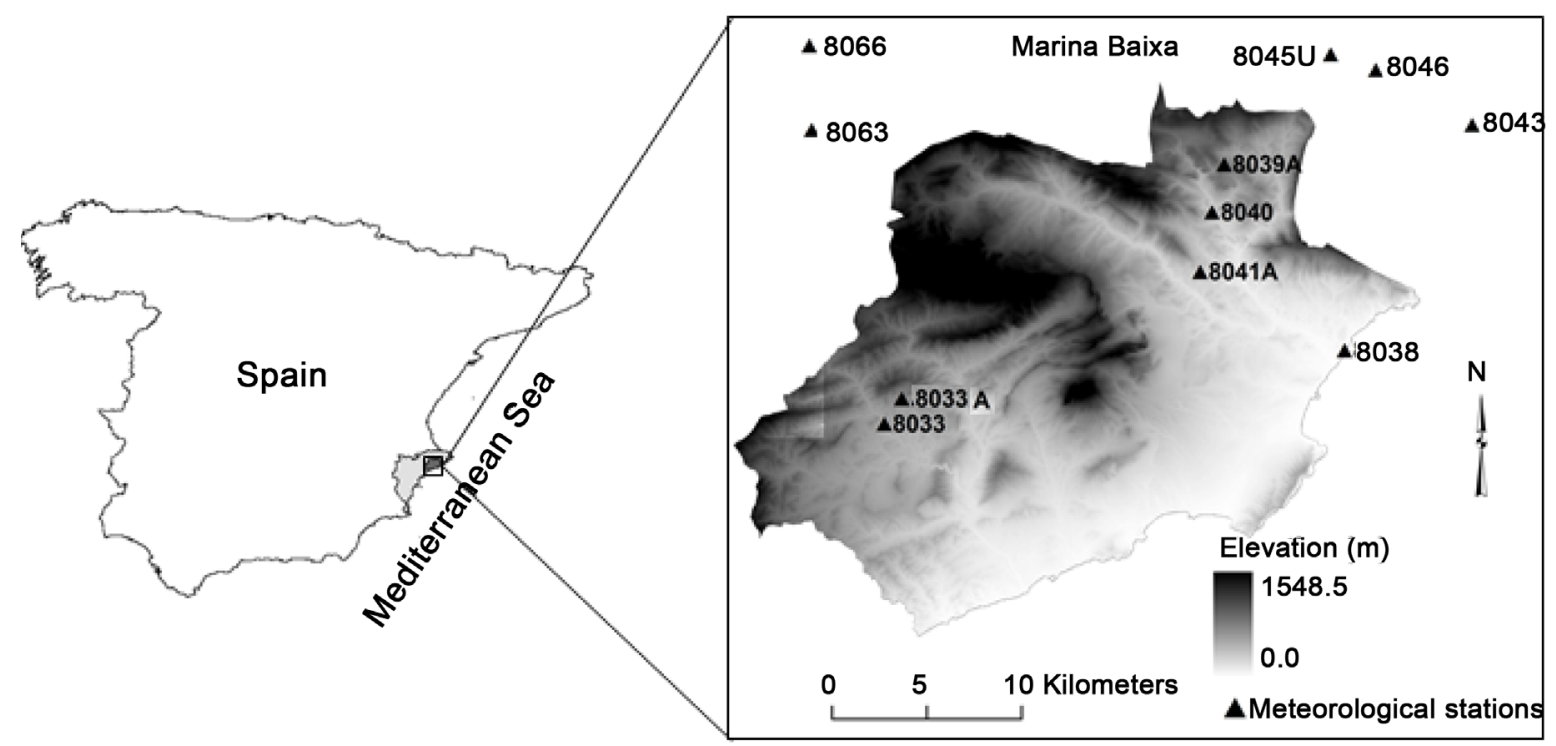

Figure 1. Location of the study area and the meteorological stations.

\subsection{Data}

To conduct this study, we used daily precipitation data, and the maximum and minimum temperatures, of eleven weather stations located inside (6 stations) and outside (5 stations) the study area (Figure 1). These data derive from a database of climate forecasts available on the Spanish State Meteorology Agency website

(http://escenarios.aemet.es/), which collects data from different GCMs. However, only three GCMs have regionalised data in weather stations. These data, generated by three GCMs (ECHAM4 (the atmosphere-oceancoupled model of the Max Plan Meteorology Institute (Germany), version 4), CGCM2 (the atmosphere-oceancoupled model of the Canadian Climate Centre, version 2), HadCM3 (the atmosphere-ocean-coupled model of the Hadley Centre (UK), version 3), have been regionalised by two empirical methods: the FIC analogues (method of Climate Research Foundation) to regionalise the data of models ECHAM4 and CGCM2, and the SDSM (Statistical Down Scaling Method) regression method for the HadCM3 model data [11]. It was considered sufficient to use only HadCM3 model data because is presents similar simulation data as the ECHAM4 model. CGCM2 model was discarded given the worse fit that it provided to reconstruct the observed period climate data in Marina Baixa. Indeed, a recent study carried out in a nearby area [12] concluded that from the above cited CGMs the HadCM3 model presented the most similar database (precipitation and air temperature) when the same years selected from the observed period were compared. Another former study carried out in Iran came to a similar conclusion [13].

The impact of climate change forecasts on the Marina Baixa region was assessed for emission Scenario A2. Scenario A2 forecasts high population growth and slow economic and technological development, where local solutions prevail with a moderate employment of energy for future time series (2011-40, 2041-70 and 2071-99). Scenario A2 was selected based on the assumption that the demographic development and growth model to follow, and its relation with the natural environment would continue with no significant changes, especially as far as the sustainability of ecosystems is concerned.

\subsection{Data Analysis}

In order to study the change dynamics of precipitations in Marina Baixa, a temporal and spatial analysis was done for the observed and projected periods. The mean annual precipitation during each projected period was calculated and compared to the observed period (1961-1990). The same analysis was done with the reference evapotranspiration (ETo) calculated by Hargreaves-Samani method [14], using observed and projected air temperature data.

To complete the analysis of precipitations in the study area, an analysis of the probability of exceedance of a threshold was done. The probability of exceedance (Pe, \%, Equation (1)) was calculated according to the dis- 
tribution of Weibull [15] and Gulinova [16]:

$$
P e=\frac{m}{n+1} * 100
$$

where $m$ is the order number of each observed value, with $m=1$ for the higher value and $m=n$ for the lower one, and $n$ is the number of observations. The study of probability of exceedance considered the $400 \mathrm{~mm}$ threshold (70\% of the mean annual precipitation of the observed period 1961-1990).

In order to assess the likely effects of climate change on agriculture, the crop growing period length (LGP) for each climatic period was estimated.The growing period is the period of the year when both moisture and temperature conditions are favorable for crop growth [17] [18]. LGP can be assessed by a simple moisture balance of precipitation (P) and reference evapotranspiration (ETo) when the temperature is not a limiting factor ( $\mathrm{T}>$ $5^{\circ} \mathrm{C}$ ) [17]. In Marina Baixa crops are grown in low altitudes where temperatures rarely go down $5^{\circ} \mathrm{C}$. The growing period (GP) is the period of consecutive decades (10-day periods) when $\mathrm{P}$ is higher or equal to the half ETo. The choice of 10-day periods as a time base for analysing water balance derives from the ability of a soil to hold rainwater and to have it available to the crop [18]. New decadal (10-days) time series of precipitation and ETo were computed to carry out this analysis. Climate model data have only 360 days; it is why only 36 decades were computed by year. Besides the decadal analysis, an exploratory analysis of LGP at a daily basis was done.

To analyse this information, applying probability methods like a frequency analysis (FA) [18] (Equation (2)) was prioritised. This method evaluates the probability of precipitation exceeding half the ETo of each decade as a percentage. With the obtained results, the growing period was obtained, and was defined as the time interval in which precipitation exceeded half the ETo for a probability of $75 \%$ or more.

$$
F A(\%)=\frac{n}{N} * 100
$$

where $n$ is the number of times that $\geq \frac{E T o}{2} ; N$ is the number of years in the data series.

The attributes of the LGP lie in precipitation acquiring ecological properties since its performance relates to being able to meet the water requirements of crops. A risk assessment is also indicated when conditioning the period to meet the conditions of exceeding $75 \%$ of probability, which is a guarantee for the crop in question. Frequency over $30 \%$ in any of the scenarios is taken as a comparison measure.

The whole database was processed by the Agroclim-Map ${ }^{\circledR}$ software [19]-[21], which allowed the computation of various agroclimatic models and indices. The output variables of these models were used as input variables for post-processing methods (statistic and geostatistic processing). The final products were tables, graphs and maps created using the Inverse Distance Weighted (IDW) interpolation method, which provided a better interpretation of the results.

\section{Results and Discussion}

\subsection{Temporal and Spatial Dynamics of Precipitations}

The spatial distribution of precipitations in Marina Baixa shows a NE-SW gradient. High precipitation values (green and yellow areas on the map) are observed in the NE of the study area and low values (red and orange areas) in the SW (Figure 2). The temporal dynamics analysis of precipitation from the observed period to the end of the present century showed a negative trend. The reduction in the mean annual precipitation, for the entire region, expected in the first projected period is less marked ( $-5 \%$ with respect to the observed period). However, the decrease is expected to be more evident in the 2041-70 and 2071-99 periods $(-14 \%$ and $-30 \%$ with respect to the observed period respectively). Frequency histograms show the percentage of the Marina Baixa territory with precipitations in a given range (Figure 2). In the observed period $20 \%$ of the territory showed precipitation values above $400 \mathrm{~mm}$, with areas reaching values above $600 \mathrm{~mm}$ near the town of Altea located in the NE. During the 2041-70 and 2071-99 periods, these areas are expected to be reduced to $10 \%$ and only $2 \%$ of the territory, respectively. These results coincide with those reported by Tatarinov [22] in Central Europe and at a global scale by IPCC [23].

The spatial analysis of precipitation in Marina Baixa and its expected changes in the future showed that the rate of change is space-dependent. Actually, despite the fact that the mean rates of change were $-5 \%,-14 \%$ and 


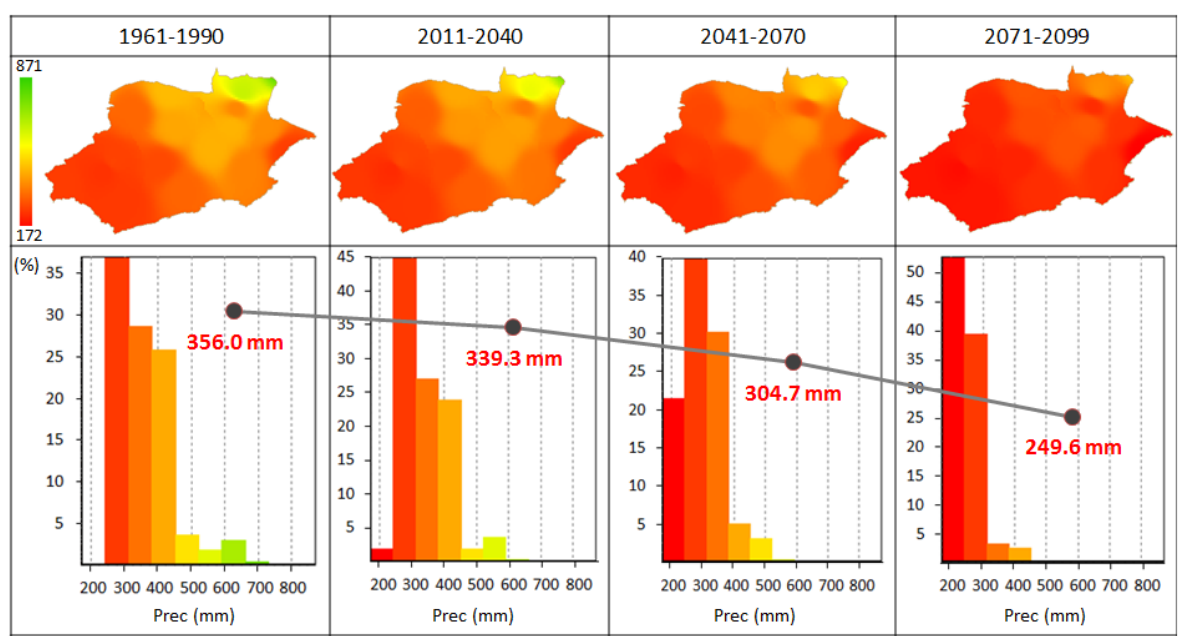

Figure 2. Temporal and spatial distribution of the mean annual precipitations during the observed and projected periods. Frequency histograms (X-axis: annual precipitation $\mathrm{mm}$ ); Y-axis: observed frequency (\%)). Grey line shows the decrease of precipitations over time.

$-30 \%$ in the 2011-40, 2041-70 and 2071-99 periods with respect to the observed period respectively, these rates were different depending on the space. Few differences found between the observed period and 2011-40 exceed $60 \mathrm{~mm}$; however, the most frequent differences were concentrated between 0 and $30 \mathrm{~mm}$. The differences found in the 2041-70 period exceeded $210 \mathrm{~mm}$, although $90 \%$ of the area showed differences below $100 \mathrm{~mm}$. In the period 2071-99 infrequent differences reached values above $300 \mathrm{~mm}$ in reduced areas while in the major part of the territory these differences fluctuated within the 50 - $250 \mathrm{~mm}$ range. Between the period 2041-70 and the period 2071-99 the areas affected by high change rates passed from $10 \%$ to $40 \%$ which coincides with results reported by Jones [24] and Whetton [25], who reported more shortages in precipitations and changes in their annual distribution. The resulting reduction in precipitations became a factor that can have serious effects on the growth of different species, as reported by several authors [3] [26] [27]. In some regions, as is the case crop growing regions of Russia, the frequency of food production shortfalls could triple by the 2070s [28].

\subsection{Probability of Exceeding the $400 \mathrm{~mm}$ Threshold of Annual Precipitation}

The mean probability of exceeding the $400 \mathrm{~mm}$ threshold (Pe400) of annual precipitation in Marina Baixa was $29 \%$ in the period $1961-1990$. This probability is expected to decline to $9 \%$ by the end of the $21^{\text {st }}$ century (Figure 3). The maps in the Figure 3 show the spatial distribution of the Pe400 where green and yellow indicate high values and red and orange low values. The histograms show the percentage of the territory with a given probability. The results of the comparison of the Pe400 in the projected periods with the observed one indicate that there will be more areas with little Pe400, while the areas with a great probability tend to lower by the end of the $21^{\text {st }}$ century (Figure 3). Probability that equalled or exceeded $60 \%$ were only significant during the observed period 1961-90 and the first projected period, whereas areas that reached this threshold was negligible in the 2041-70 period, and null in the last period 2071-99 (Figure 3). Similar results were reported by Alcamo et al. [28]. The spatial analysis of the territorial distribution of the probability of exceedance in the study area is essential. If not, extreme values can be confusing when making comparisons because they can obtain higher or lower values, but in small areas. This became evident when comparing the observed period with the period 2011-2040, where the distribution of the values provided a more exact image of the true effect of territory, even when values appeared with similar magnitudes.

\subsection{Temporal and Spatial Dynamics of Reference Evapotranspiration (ETo)}

The spatial distribution of the reference evapotranspiration follows the same distribution as temperature, low values in the northern and coastal areas and high values in the southern and inland areas (Figure 4). Over time the ETo showed inverse trends in comparison with precipitation. In fact, the expected increment in air temperature will cause an increase in ETo (Figure 4). The observed mean value of ETo for the entire region is about 


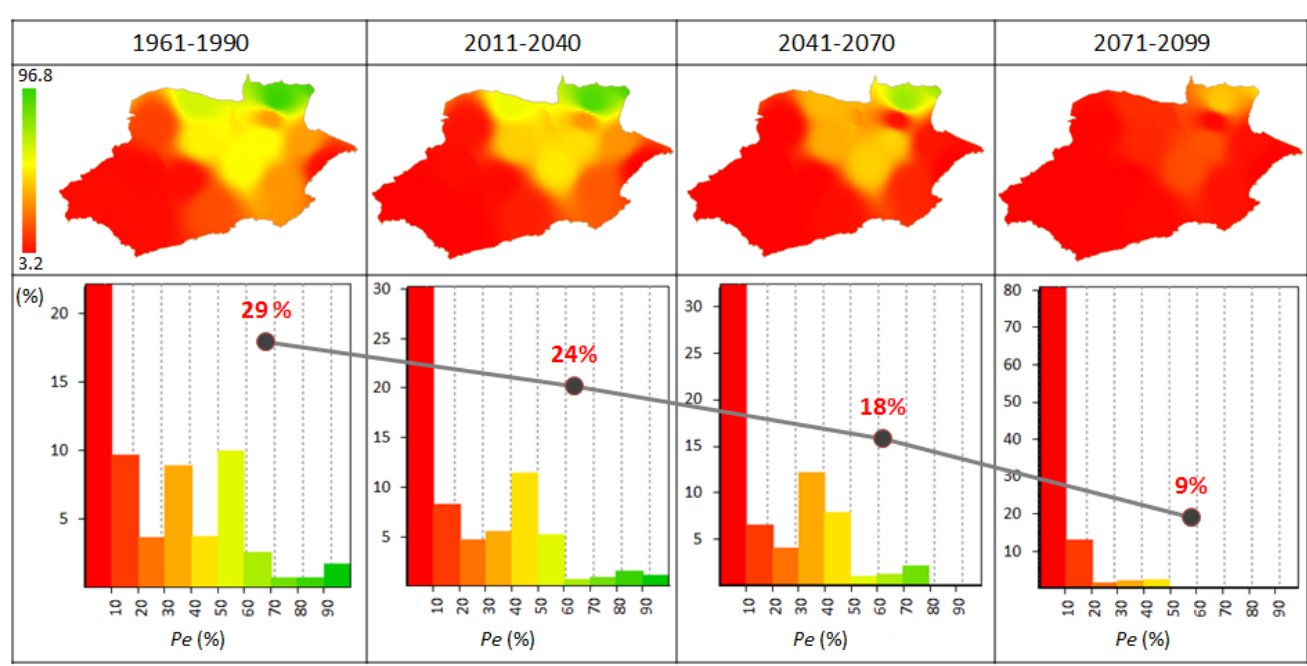

Figure 3. Temporal and spatial distribution of probability of exceeding $400 \mathrm{~mm}$ of annual precipitation during the observed and projected periods. Frequency histograms (X-axis: Probability of exceedance (\%)); Y-axis: observed frequency (\%)). Grey line shows the decrease of probability of exceeding $400 \mathrm{~mm}$ of annual precipitation over time.

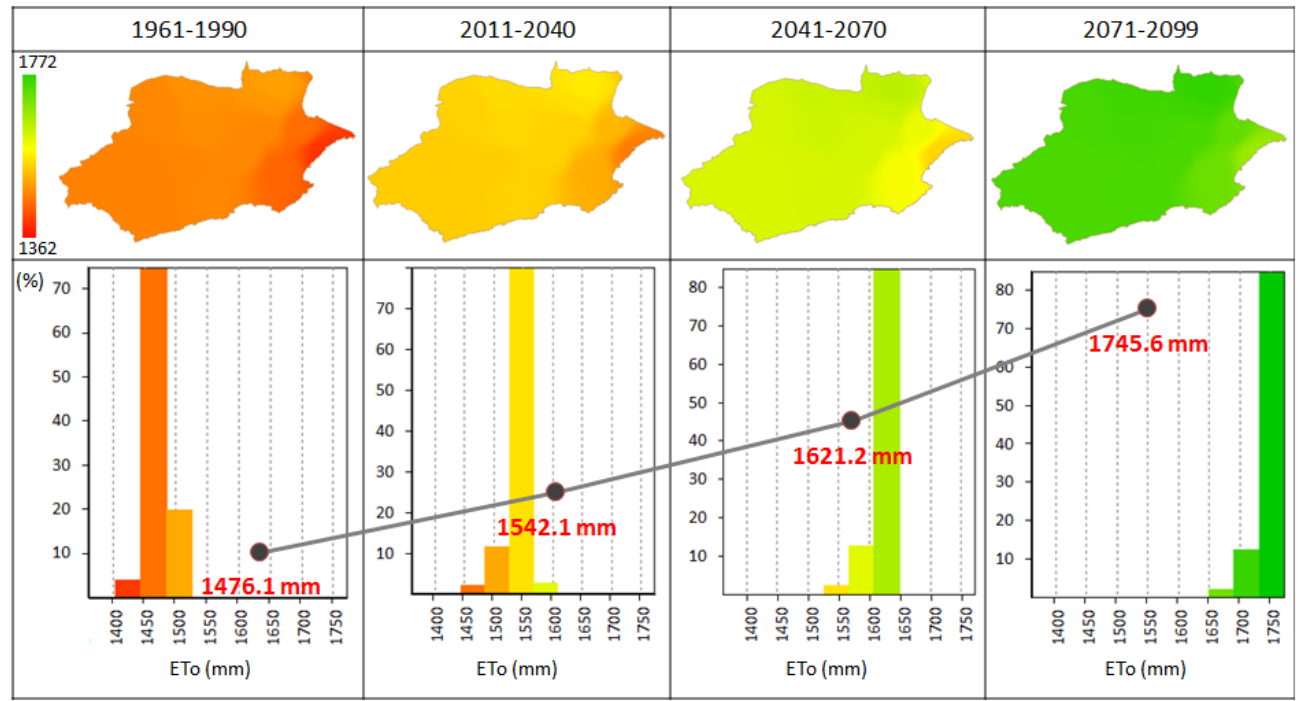

Figure 4. Temporal and spatial distribution of the mean annual ETo during the observed and projected periods. Frequency histograms (X-axis: annual ETo mm); Y-axis: observed frequency (\%)). Grey line shows the increase of ETo over time.

$1476 \mathrm{~mm}$. This value is expected to rise more slightly in the first projected period ( $+4 \%$ with respect to the observed period) and with higher rates in the second and third projected periods $(+10 \%$ and $+18 \%$ with respect to the observed period respectively). These changes are expected to show some homogeneity throughout the study area where no contrasts are obtained in the obtained in the reference evapotranspiration values shown in the maps. These results are similar to those obtained by Whetton [28], who considered that lack of humidity would increase, along with a rise in temperatures, a trend that is related with increased evapotranspiration. In some experiments, the increase of $3.5^{\circ} \mathrm{C}$ found by some models could determine an increase in evapotranspiration of $13.8 \%$ [29].

\subsection{Analysis of the Length of the Growing Period (LGP)}

\subsubsection{Balance between Precipitation and ETo at a Daily Basis}

The LGP can be computed as the consecutive periods of time when P exceeds half the ETo with a probability of 75\%. As an exploratory analysis we analysed the balance between P and ETo at a daily basis computing the 
days when P exceeds half the ETo with a probability of $75 \%$. The balance showed very low values, which ranged from 0 to 10 days. The resulting balance between precipitation and reference evapotranspiration was negative for more than $90 \%$ of the days of the year. Although rainfall a certain number of years was higher than the ETo, it does not exceed the probability of $75 \%$ of the population $(30 \times 0.75=22.5$ years $)$ due the torrential regime of precipitation and their high inter-annual variability in the region [30]. The spatial and temporal analysis of the balance between P and ETo in Marina Baixa showed low values varying between 0 and 10 days in the observed period with high values in the north part and very low values in the south part. In the periods 2011-40 and 2041-70 the balance showed values between 1 and 2 days, whereas in the last projected period (2071-99) there were null days throughout the study area.

\subsubsection{Analysis of the Length of Growing Period (LGP) and Its Projected Evolution}

In this section the LGP was computed as the consecutive decadal periods (10-day periods) when P exceeds half the ETo. However, as in the case of the daily basis, the probability that P exceeds half the Eto reached the 75\% threshold only in very few decades in just one of the eleven meteorological stations used. Therefore, the use of the $75 \%$ probability threshold to assess LGP in Marina Baixa was not feasible. After exploring the use of other threshold, we chose the $30 \%$ threshold because it marks the beginning and end of the rainy season in the region. On the one hand, when the probability that P exceeds, half the Eto starts going up $30 \%$ between the $26^{\text {th }}$ and $29^{\text {th }}$ decade (September to October), this marks the start of the autumn rainfalls. On the other hand when this probability starts going under $30 \%$ between the $7^{\text {th }}$ and $13^{\text {th }}$ decade (March to May), it marks the end of the spring rainfalls. The growing period starts in a year and end in the next year in the Mediterranean region which coincide with hydrological year.

Figure 5 presents the FA graphs in two weather stations inside Marina Baixa limits, 8033 and $8041 \mathrm{~A}$ for the observed and projected periods. These two stations, situated in the SW and NE respectively, are representative of the regional climatic conditions. In the two stations the probability that P exceeds half the ETo never reaches the $75 \%$ threshold in the four periods. Station 8033 showed a large interval of time with low frequencies in general and very low frequencies $(<30 \%)$ between the $6^{\text {th }}$ decade and $29^{\text {th }}$ decade in the observed period which means a shorter LGP (blue area in the left graphs in Figure 5). Station 8041A, in comparison with station 8033, showed a short interval of time with low frequencies $(<30 \%)$ in the observed period (from the $13^{\text {th }}$ decade to the $26^{\text {th }}$ ) which means a larger LGP (blue area in the right graphs in Figure 5). This interval of time is expected to increase in the projected periods in both stations with a slight high rate of change in station 8041A in comparison with the station 8033. This means that the LGP is expected to be shorter by the end of the $21^{\text {st }}$ century.

Table 1 summarises all the FA results and the LGP at the six stations inside the study area limits, and for all the simulation periods. The observed LGP starts in the beginning of the last quarter of a year $\left(26^{\text {th }}\right.$ to $29^{\text {th }}$ decades) and end in the next year ( $7^{\text {th }}$ to $13^{\text {th }}$ decade) taking into account that in this work the year has 360 days and 36 decades. In the observed period the mean value of LGP varies between SW and NE (150 and 230 days respectively). The LGP is shorter (150 - 180 days) in SW and coastal stations and larger (220 - 230) in the NE stations with the exception of station 8040. The LGP is expected to decrease by the end of the $21^{\text {st }}$ century in the six stations. Indeed, in the SW and coastal stations the LGP is expected to decrease by 60 to 70 days in the last projected period (2071-99) while in NE stations the reduction will be about -40 to -50 days. The contrast between NE and SW is due the differences in precipitations and ETo between the two regions. Precipitations are higher and temperatures are lower in the NE and changes in LGP will be proportional to change in these two climatic variables.

\section{Conclusion}

The results show that a decrease in the annual total precipitation is expected towards the end of this century ( $-30 \%$ in the period 2071-99 with respect to the observed period (1961-1990)). Besides this change in the mean, the probability of exceeding the $400 \mathrm{~mm}$ threshold of annual precipitation is expected to decrease from $29 \%$ in the observed period to $9 \%$ in the last projected period. In contrast, an increase of $+18 \%$ in the ETo is expected. Therefore these forecasts in the climatic conditions will produce a reduction in the crop growing period length assessed by a balance between precipitation and ETo. This result indicates that the region of Marina Baixa will face a big challenge in terms of water insufficiency in the future, which can only be overcome through mitigation and adaptation actions. A possible alternative could be to consider the use varieties of crops with short growing season and to design infrastructures for irrigation to meet the water needs of crops of interest. 

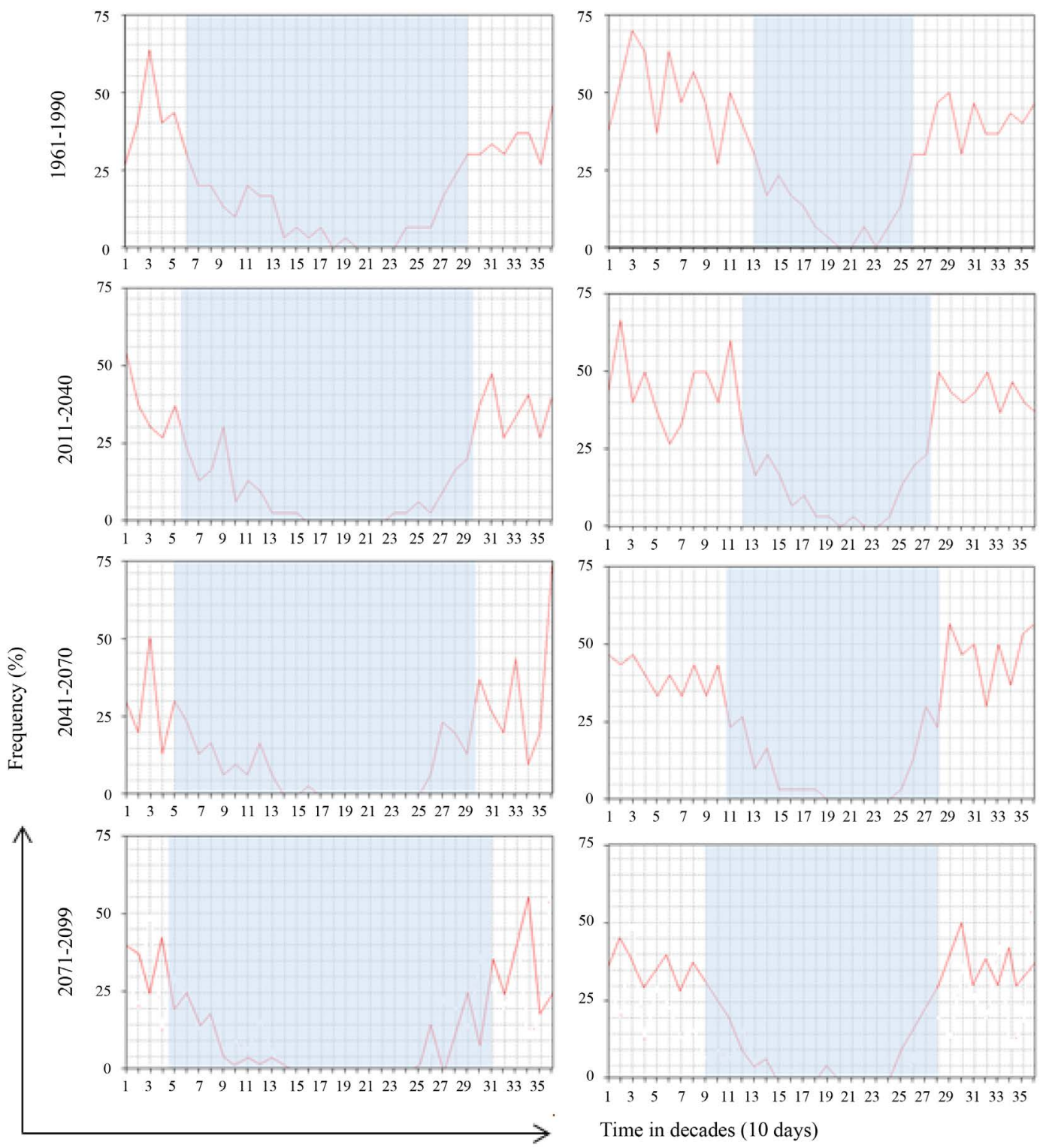

Figure 5. Frequency analysis of P exceeding half the ETo in the stations 8033 (left) and 8041A (right) during the observed and projected periods. (Blue area shows the decades when the frequency goes down $30 \%$ ).

Table 1. LGP in Marina Baixa using the $30 \%$ threshold of probability that P exceeds half the ETo. Start and end decades and duration in days. LGP start in a year and end in the next year.

\begin{tabular}{ccccc}
\hline $\begin{array}{c}\text { Meteorological } \\
\text { Stations }\end{array}$ & $1961-90$ & $2011-40$ & $2041-70$ & LGP start and end decades and duration in days \\
\cline { 2 - 4 } & $29-8(150)$ & $30-6(120)$ & $30-6(120)$ & $31-4(90)$ \\
8033 & $28-10(180)$ & $26-12(220)$ & $28-6(140)$ & $29-5(120)$ \\
$8033 \mathrm{~A}$ & $28-7(150)$ & $29-10(170)$ & $28-6(140)$ & $32-4(80)$ \\
8038 & $28-9(170)$ & $27-10(190)$ & $28-6(140)$ & $28-7(150)$ \\
8040 & $26-13(230)$ & $26-14(240)$ & $28-12(200)$ & $27-10(190)$ \\
$8039 \mathrm{~A}$ & $26-12(220)$ & $27-12(210)$ & $28-9(170)$ & $28-9(170)$ \\
\hline
\end{tabular}




\section{Acknowledgements}

This research was partially funded by the Spanish Government, through the Ministry of Economy, ECOBAL project (CGL2011-30531-C02-01). Chirino, E. thanks the Prometheus Project (SENESCYT, Ecuador) for funding his grant. The authors would also thank the Spanish meteorological agency (AEMET) for the climatic data.

\section{References}

[1] IPCC (2007) Tercer Informe de Evaluación. Cambio Climático 2007, la base científica.

[2] IPCC (2013) Informe de Evaluación. Cambio Climático 2013, la base científica.

[3] Aber, J.D., Ollinger, S.V., Federer, C.A., Reich, P.B., Goulden, M.L., Kicklighter, D.W., Melillo, J.M. and Lathrop, R.G. (1995) Predicting the Effects of Climate Change on Water Yield and Forest Production in the Northeastern United States. Climate Research, 5, 207-222. http://dx.doi.org/10.3354/cr005207

[4] Churkina, G., Running, S.W., Schloss, A.L., and the Participants of the Potsdam NpP. Model Intercomparison (1999) Comparing Global Models of Terrestrial Net Primary Productivity (NPP): The Importance of Water Availability. Global Change Biology, 5, 46-55. http://dx.doi.org/10.1046/j.1365-2486.1999.00006.x

[5] Davi, H., Dufrêne, E., Francois, C. ,Le Maire, G., Loustau, D., Bosc, A. and Moors, E. (2006) Sensitivity of Water and Carbon Fluxes to Climate Changes from 1960 to 2100 in European Forest Ecosystems. Agricultural and Forest Meteorology, 141, 35-56. http://dx.doi.org/10.1016/j.agrformet.2006.09.003

[6] Ozenda, P. and Borel, J.-L. (2000) An Ecological Map of Europe: Why and How? Comptes Rendus de l'Académie des Sciences-Series III-Sciences de la Vie/Life Sciences, 323, 983-994.

[7] Smith, J.B., et al. (2001) Vulnerability to Climate Change and Reasons for Concern: A Synthesis. In: McCarthy, J.J., Canziani, O.F., Leary, N.A., Dokken, D.J., White, K.S., Eds., Climate Change 2001: Impacts, Adaptation, and Vulnerability: Contribution of Working Group II to the Third Assessment Report of the Intergovernmental Panel on Climate Change, Cambridge University Press, Cambridge, 913-967.

[8] Giannakopoulos, C., Le Sager, P., Bindi, M., Moriondo, M., Kostopoulou, E. and Goodess, C.M. (2009) Climatic Changes and Associated Impacts in the Mediterranean Resulting from a $2{ }^{\circ} \mathrm{C}$ Global Warming. Global and Planetary Change, 68, 209-224.

[9] Katz, R.W. and Brown, B.G. (1992) Extreme Events in a Changing Climate: Variability Is More Important than Averages. Climatic Change, 21, 289-302. http://dx.doi.org/10.1007/BF00139728

[10] Peña, J. (2007) Efectos ecológicos de los cambios de coberturas y usos del suelo en la Marina Baixa (Alicante). Tesis presentada en opción al título de Doctor en Ciencias, Universidad de Alicante, España.

[11] Brunet, M., Casado, M.J., de Castro, M., Galán, P., López, J.A., Martín, J.M., Pastor, A., Petisco, E., Ramos, P., Ribalaygua, J., Rodríguez, E., Sanz, I. and Torres, L. (2009) Generación de escenarios regionalizados de cambio climático para España. Ministerio de Medio Ambiente y Medio Rural y Marino, Agencia Estatal de Meteorología, Madrid, 158 p.

[12] Touhami, I., Chirino, E., Andreu, J.M., Sánchez, J.R., Moutahir, H. and Bellot, J. (2015) Assessment of Climate Change Impacts on Soil Water Balance and Aquifer Recharge in a Semiarid Region in South East Spain. Journal of Hydrology, 527, 619-629. http://dx.doi.org/10.1016/j.jhydrol.2015.05.012

[13] Samadi, S.Z., Sagareswar, G. and Tajiki, M. (2010) Comparison of General Circulation Models: Methodology for Selecting the Best GCM in Kermanshah Synoptic Station, Iran. International Journal of Global Warming, 2, 347-365. http://dx.doi.org/10.1504/IJGW.2010.037590

[14] Hargreaves, G.H. and Samani, Z.A. (1985) Reference Crop Evapotranspiration from Temperature. Applied Engineering in Agriculture, 1, 96-99. http://dx.doi.org/10.13031/2013.26773

[15] Weibull, W. (1961) Fatigue Testing and Analysis of Results. Pergamon, Oxford, 225.

[16] Gulinova, N.V. (1974) Métodos Agroclimáticos de Elaboración de las Observaciones. Guidrometeoizdat, Leningrado, $151 \mathrm{p}$.

[17] Agriculture Organization of the United Nations, Soil Resources, Management \& Conservation Service (1996) Agro-Ecological Zoning Guidelines No. 73. Food and Agriculture Organization.

[18] Eldin, M. and Rojas, O. (1983) A System of Agroclimatic Zoning to Evaluate Climatic Potential for Crop Production. In: Cusak, D.F., Ed., Agroclimatic Information for Development: Reviving the Green Revolution, Westview, Boulder, 83-91.

[19] Herrera, M.S. (2000) Contribución metodológica a la zonificación agroclimática de la caña de azúcar: Caracterización agroclimática de las áreas cañeras de la provincia La Habana. Tesis en opción al grado de Doctor en Ciencias Agrícolas. Universidad Agraria de la Habana, La Habana. 
[20] Herrera, M. and González, C. (2007) AgroClim: Un software para la ciencia y la docencia. Premio Relevanteen Fórum Provincial, Ciudad Habana, Cuba.

[21] González, C.A., Moutahir, H., Herrera, M., Zayas, L., Touhami, I. and Bellot, J.F. (2012) Agroclim-Map, a GIS Application for Agroclimatic Systems Analysis. Proceedings of the International Conference of GIS Users, Taza GISDays, Morocco, 23-24 May 2012, 491-493.

[22] Tatarinov, F. and Cienciala, E. (2009) Long-Term Simulation of the Effect of Climate Changes on the Growth of Main Central-European Forest Tree Species. Ecological Modelling, 220, 3081-3088.

[23] IPCC (2014) Climate Change 2014: Impacts, Adaptation, and Vulnerability. Part A: Global and Sectoral Aspects. Contribution of Working Group II to the Fifth Assessment Report of the Intergovernmental Panel on Climate Change. Cambridge University Press, Cambridge and New York, 1132 p.

[24] Jones, R. (1996) Climate Change Scenarios for the Australian Region. CSIRO Atmospheric Research, Aspendale.

[25] Whetton, P. (2001) Climate Change: Projections for Australia. CSIRO Atmospheric Research Report, Aspendale.

[26] Tatarinov, F., Bochkarev, Y., Oltchev, A., Nadezhdina, N. and Cermak, J. (2005) Effect of Contrasting Water Supply on the Diameter Growth of Norway Spruce and Aspen in Mixed Stands: A Case Study from the Southern Russian Taiga. Annals of Forest Science, 62, 807-816. http://dx.doi.org/10.1051/forest:2005086

[27] Vygodskaya, N.N., et al. (2004) Long-Term Dynamics of Soil Moisture and Drying of Spruce Trees in Spruce Forests of the Southern Taiga. Russian Forest Sciences (Lesovedenie), 1, 3-22. (In Russian)

[28] Alcamo, J., Dronin, N., Endejan, M., Golubev, G. and Kirilenko, A. (2007) A New Assessment of Climate Change Impacts on Food Production Shortfalls and Water Availability in Russia. Global Environmental Change, 17, 429-444. http://dx.doi.org/10.1016/j.gloenvcha.2006.12.006

[29] Finnerty, B. and Ramirez, J.A. (1995) Impact Assessment Study of Climate Change on Evapotranspiration and Irrigated Agriculture in the San Luis Valley, Colorado. Proceedings of the AWRA 31st Annual Conference and Symposia, Houston, 5-9 November 1995. http://www.nws.noaa.gov/oh/hrl/papers/area/sanluisb.htm

[30] Hidalgo, J.G., De Luis, M., Raventós, J. and Sánchez, J.R. (2003) Daily Rainfall Trend in the Valencia Region of Spain. Theoretical and Applied Climatology, 75, 117-130. 